\title{
1
}

\section{Maritime/Marine Spatial Planning at the Interface of Research and Practice}

\author{
Charles Ehler, Jacek Zaucha, and Kira Gee
}

\section{Introduction to the Growing Practice of MSP}

Marine/maritime spatial planning (MSP) is about managing the distribution of human activities in space and time to achieve ecological, economic and social objectives and outcomes. It is a political and social process informed by both the natural and social sciences. Over the last 20 years, MSP has matured from a concept to a practical approach to moving towards sustainable development in the oceans. Integrated marine spatial plans have been implemented by about 20 countries, and it is expected that by 2030, at least a third of the surface area of the world's exclusive economic zones will have governmentapproved marine spatial plans (Ehler 2017).

Academic interest in MSP has grown exponentially over the past decade. A November 2017 search of the "Web of Knowledge" of the Institute for Scientific Information (ISI) found over 900 scientific papers on MSP pub-

\section{Ehler $(\bowtie)$}

Intergovernmental Oceanographic Commission (IOC) of the United Nations Educational, Scientific and Cultural Organisation (UNESCO), Paris, France e-mail: charles.ehler@mac.com

\section{J. Zaucha}

Institute for Development and Maritime Institute, University of Gdańsk, Gdańsk, Poland

K. Gee

Human Dimensions of Coastal Areas, Helmholtz Zentrum Geesthacht, Geesthacht, Schleswig-Holstein, Germany 
lished in international peer-reviewed journals and almost 10,000 articles in Google Scholar when searching for "marine spatial planning" alone (Santos et al. in press). According to Merrie and Olssen (2014), much of this increase in academic interest in MSP seems to have been derived from the first international workshop on MSP organised by the Intergovernmental Oceanographic Commission (IOC) of the United Nations Educational, Scientific and Cultural Organization's (UNESCO) in 2006. The 2nd International Conference on Marine/Maritime Spatial Planning, organised by IOCUNESCO and the European Union (EU) and held in Paris in 2017, attracted over 700 applicants, reflecting the growing interest in the topic from a practical perspective. ${ }^{1}$ Many scientific conferences such as the Annual International Council for the Exploration of the Sea (ICES) Sciences Conference are now regularly offering sessions on MSP, and a dedicated MSP Research Network has emerged, founded at the University of Liverpool with numerous subgroups focusing on specific topics.

\section{The Imperative for a Multidisciplinary Approach in MSP}

The imperative for employing a multidisciplinary approach stems from the nature of marine space as a multi-dimensional concept requiring insight from many scientific disciplines and types of knowledge (Ansong et al. 2018). Space is the subject of research and investigation by physicists, biologists, geographers, economists, political scientists, spatial planners, sociologists, philosophers and scholars of culture. As Faludi notes $(2013,8)$, "Territory is not necessarily a fixed entity enveloping all major aspects of social and political life within its boundaries. Rather, it is the object of negotiation and compromise, open to multiple interpretations." Space-and with this, marine space-must therefore be seen as a dynamic entity composed of a multitude of interrelations.

A key premise is that there is no single maritime space and that each of its delimitations is arbitrary. We are dealing with a number of overlapping sea spaces, each of which has its very own constituting relationships. For instance, many decisions concerning MSP are made in metropolitan centres far away from the coast, which is why maritime space in the regulatory dimension can have a discontinuous, network-like character. This is also the case with economic issues, illustrated by the fact that many of the economic benefits generated in the sea are realised far inland. At the same time, many traditional boundaries in the sea are currently dissolving. These include boundaries

\footnotetext{
${ }^{1}$ www.msp2017.paris/.
} 
between state and economic actors, for example, or boundaries of perception, and even national and other administrative boundaries and borders. In various senses of the word, marine space is losing its traditional role as a frontier, instead becoming a contact point and boundary object for a variety of political, economic and environmental interests and views.

The definition of what exactly constitutes maritime space, and therefore the object of planning efforts, is a key challenge for spatial approaches to management. Where does the use of land affect the sea and the use of the sea affect the land? As each affects the other to some extent, is their separation in MSP not merely an artificial exercise? Similarly, ecological or cultural marine spaces may easily extend across land and water, giving rise to complex administrative and political questions. Some scholars have taken these notions even further, moving away from the consideration of "being" in the context of the sea and concentrating instead on the processual "becoming", understanding oceans as a mobile and processional entity in line with their constantly changing nature (Anderson and Peters 2014). Given the changeable character of the space, ecosystems and societies that constitute the ocean, it is therefore all the more important to consider the dynamic and process-oriented nature of MSP rather than any static outcomes it may produce. Analysing and shaping MSP in this specific context-dealing with multiple concepts of space and associated actors and stakeholders, dynamic yet also seeking stability as part of administrative processes and legislative frameworks - requires a multidisciplinary approach, drawing on the knowledge of different disciplines.

Another reason for MSP to take a multidisciplinary approach is its link to the sustainability discourse (see also Chap. 8 in this book). Seas and oceans are vulnerable ecosystems that consist of interrelated biological, chemical and physical processes. They provide humankind with numerous ecosystem goods and services, as well as abiotic benefits such as wind for offshore wind farming or navigation routes for shipping. Preserving them and securing their proper development is therefore of key importance to humankind. The ecosystembased approach to marine spatial governance has been proposed as a central tool for achieving this overarching goal (see e.g. Carneiro 2013; Jay 2012; Douvere 2008; Gilliland and Laffoley 2008), but this poses new questions as to how to combine sustainable use of natural resources and the preservation of ecologically valuable species and habitats (Hassler et al. 2017). The central dilemma of sustainable development-how to simultaneously preserve and exploit ecosystems — also applies to the sea, perhaps even more so because in many respects, the oceans are still poorly understood.

A new sense of the ocean is also manifesting itself in the context of economics. This is exemplified in the popularity of the concept of "blue growth" 
most recently introduced by the Organisation for Economic Co-operation and Development (OECD) and European Commission (see also Chaps. 5 and 6 in this book). As stated by the European Commission (EC 2016, 2), for the EU and many nations around the world, oceans hold a key to the future. According to the OECD, in 2010 the blue economy resulted in global products and services worth US $\$ 1.5$ trillion, or $2.5 \%$ of the world gross value added, providing 31 million jobs (OECD 2016, 13). New ways of reaping the benefits of ocean space are emerging (EC 2014b), and current uses are undergoing profound transformations (Zaucha 2009). Many emerging activities have strong transboundary dimensions, with traditional uses also facing increasing pressure to transnationalise. As a result, ever more international maritime networks are emerging — of sea basin transmission grids, shipping routes or transnational oil pipelines, in particular, in enclosed seas such as the Baltic or the Mediterranean. But the resulting pressures are rarely restricted to particular areas or sea spaces either. Even physically constrained maritime activities can have profound impacts on the surrounding maritime space-in the case of pollution or underwater noise, sometimes across very long distances. Transboundary approaches are therefore called for not only in economic development but also in resource management and protection (see also Chaps. 3 and 4 in this book).

From a research perspective, a key question is thus whether maritime development is simply the next stage in our emancipation from the geographical determinism first proposed by Ratzel (1882). The environment has long since ceased to determine human activities on land, but will we witness the same development in the sea? And what does this imply for marine governance including MSP? What will be the guiding principles of these developments, and what priorities will we set for the ocean? There are some indications that a new social awareness is emerging of the seas, driven by recent issues such as marine pollution and the powerful imagery that has now become available on life in the ocean (see also Chap. 7 in this book). Societies are reassessing the value they are placing on the ocean and are becoming more aware of its role in well-being and quality of life. Just like governance itself, the shifting values and beliefs about the ocean are also a topic for research, as these will guide our management approaches of the future-linking back to the sustainability discourse referred to earlier. 


\section{Origins and Development of MSP}

The emergence of MSP is usually ascribed to the increasing intensity of maritime use, exceeding the capacity of marine areas to meet all demands simultaneously. Access to marine space is usually not restricted, potentially leading to overuse and conflicts. As many marine goods and services are not priced in the market, conflicts often cannot be resolved through economic analysis alone (Ehler 2017). MSP has so far developed as a new governance regime under the so-called public choice mechanism. Public choice is important as ocean space is not (yet) traded in the market, therefore requiring democratic decision-making in order to avoid risks of overexploitation (the tragedy of the commons). Usually in public choice, selected representatives are expected to make specific decisions; in this case, decisions on how marine space should be used. Public choice decision-making also entails consideration of important societal values such as biodiversity or social justice. For public choice mechanisms to work well, proper process and the involvement of all stakes are crucial (see also Chaps. 9, 10 and 13 in this book).

The idea that became MSP was initially proposed in 1976 by international and national interests in developing marine protected areas as a response to the environmental degradation of marine areas caused by human activities (Olsson et al. 2008). In the early 1980s, zoning plans were created for the Great Barrier Reef in Australia (Day 2002), although in Europe at least this did not lead to a more comprehensive debate concerning the essence of MSP. The Great Barrier Reef zoning plans also had a primary goal of marine conservation-a very different character and scope to the multiple-objective marine/maritime spatial plans currently being created in Europe and elsewhere.

The European discussion surrounding the possibility of spatial planning in the sea began in earnest around 2000, with the first mention of the term MSP in 2001 (VASAB 2001). A veritable explosion of publications occurred in the years 2007-2009, mostly composed of policy documents and handbooks indicative of a more practical engagement with MSP (EC 2007a, b, 2008b; Ehler and Douvere 2007; Acker and Hodgson 2008; Ekebom et al. 2008; Schultz-Zehden et al. 2008; Zaucha 2008; Ehler and Douvere 2009). The first academic papers concerned with the concept and practical implementation of MSP also appeared at this time (Douvere and Ehler 2008). At this point, the first maritime spatial plan in the EU had been elaborated, namely by the German federal state of Mecklenburg-Vorpommern for its territorial sea, which was approved in 2005 (Heinrichs et al. 2005). 
The real breakthrough, however, came with the EU integrated maritime policy, as outlined in the Green Book (EC 2006) and Blue Book (EC 2007a) and presented, in detail, in the EU Action Plan (EC 2007b). This was followed by the publication of the "Roadmap for Maritime Spatial Planning: Achieving Common Principles in the EU" (EC 2008b), which describes MSP as "providing a framework for arbitrating between competing human activities and managing their impact on the marine environment". Its objective is described as "balancing sectoral interests and achieve sustainable use of marine resources in line with the EU Sustainable Development Strategy". It also stresses that MSP is a process involving data collection, stakeholder consultation and participatory development of a plan, including a process of monitoring and review.

The driving force of this debate were studies conducted by UNESCO, ${ }^{2}$ VASAB $^{3}$ and the European Commission, as well as a broad range of EU-funded pilot projects on MSP in European sea basins. ${ }^{4}$ In 2014 the MSP Directive (EC 2014a) was officially adopted. It obliges coastal EU member states to prepare maritime spatial plans by March 2021 and sets out a range of minimum requirements for these plans, such as giving consideration to land-sea interactions, considering environmental, economic, social and safety aspects, ensuring coherence between MSP and other processes such as integrated coastal management, ensuring the involvement of stakeholders and transboundary cooperation between member states and with third countries.

The exact nature of MSP, and what it can achieve as part of a legal process, continues to be contentious. This is illustrated by contrasting two views. According to a widely-used definition by UNESCO (Ehler and Douvere 2007), "MSP is a public process of analysing and allocating the spatial and temporal distribution of human activities in marine areas to achieve ecological, economic, and social objectives that are usually specified through a political process". VASAB, on the other hand, argues that MSP should be treated as a legally defined hierarchical process that aims to find a compromise between competing user needs (on the surface of the sea, in its waters and on the sea floor) in accordance with the values and objectives of a given community. These values and objectives are set out in international and state priorities and agreements. Furthermore, spatial development of marine areas should be

\footnotetext{
${ }^{2}$ Ehler, C., Douvere, F. (2009). Marine Spatial Planning: a step-by-step approach towards ecosystembased management. Paris: Intergovernmental Oceanographic Commission, UNESCO. IOC Manual \& Guides No. 53, IOCAM Dossier No. 6.

${ }^{3}$ Visions and strategy related to the Baltic Sea, cooperation of the Baltic ministers of spatial planning — cf. Zaucha (2013).

${ }^{4}$ See EU projects and initiatives on the MSP Platform website, www.msp-platform.eu.
} 
shaped by using proper instruments, including visions and strategies (Zaucha 2008 , 2). The first difference thus concerns the broader framework of the planning process itself: According to UNESCO, it is a public process, while for VASAB it is a hierarchical and legally- defined process, although the element of axiological choice - that is, the framing of objectives - is placed outside the framework of MSP. UNESCO advocates the paradigm of sustainable development; VASAB, on the other hand, does not specify this directly. UNESCO limits MSP to the allocation of marine space, and VASAB focuses on the ensuing consequences of such actions, although the UNESCO documents also indicate a similar belief in this respect (Ehler 2014).

Currently, the most frequently- used definition of MSP in Europe is the definition derived from the EU MSP Directive. This refers to "spatial planning of sea" areas as a "process through which appropriate organs of member states analyse and organise human activity in sea areas in order to achieve ecological, economic and social objectives" (EC 2014a, 140). This definition is brief and general in terms of the methods that are to be employed, and it narrows down the process to one conducted by public administrationswhich seems restrictive, although it makes sense from the perspective of the Directive which persuades member states to engage in this kind of planning.

Not least through the many pilot projects and initiatives on MSP that have taken place in Europe, but also from applying MSP in national and subnational contexts, different approaches have emerged for initiating and carrying out MSP. These are dependent on the respective definition and rationale of MSP and generally vary between a more environmental or economic focus and a more strategic or conflict resolution focus. Language is an indication of these differences, expressed in the name of MSP as either maritime spatial planning (EC 2007a, 2014a; Acker and Hodgson 2008, 1; Schultz-Zehden et al. 2008, 11) or marine spatial planning (Ekebom et al. 2008, 4; Ehler and Douvere 2009, 7; Tyldesley 2004, 1; MSPP 2006, 1; IOPTF 2010, 47; SWAM 2014; Ehler 2014; Blasbjerg et al. 2009; HM Government 2011). While some use the terms interchangeably, they do seem to reflect a slightly different understanding of the significance and role of MSP. The tradition of the European Commission (which uses the term maritime) translates into minimising conflicts between maritime sectors, while the approach of UNESCO (which uses the term marine) focuses on the ecological and environmental issues encapsulated within such planning. $\operatorname{OECD}(2016,21)$ proposes the following differentiation of those terms: The term ${ }^{5}$ maritime should be understood as "being connected with the sea, especially in relation to seafaring, commercial

\footnotetext{
5 "Maritime" will be understood as "being connected with the sea, especially in relation to seafaring, commercial or military activity", while "marine" will be understood as "of, found in, or produced by the sea, 'marine plants'; 'marine biology".
} 
or military activity", while "marine" should be understood as "of, found in, or produced by the sea, 'marine plants'; 'marine biology". Cormier et al. (2015, 1) apply the term maritime in relation to economic connotations and marine in relation to ecological ones. The practice of planning, however, does not always confirm this semantic dichotomy as, for example, in England the spatial planning of sea areas is oriented towards economy despite the fact that the term marine is used (see also Douvere and Ehler 2009a, b; Jay et al. 2013).

Table 1.1 collects the most important MSP principles set out by international decision-making bodies around the same time during the initial, constituting phase of MSP: VASAB (Zaucha 2008, 4), VASAB along with Helsinki Commission (HELCOM) ${ }^{6}$ (cf. Zaucha 2014) as well as the European Commission (EC 2008b, 10-13). Despite striking similarities, these also highlight the differing underlying values of the proposing organisations. VASAB, for example, in conjunction with HELCOM, an advocate of ecology-related issues, initiated a catalogue of principles that starts with sustainable development and the ecosystem approach. The European Commission, in contrast, as well as the original concept put forward by VASAB prioritises spatial efficiency, that is, the role of MSP in minimising of spatial conflicts.

\section{Common Denominators for MSP}

Despite the various differences highlighted above, there are many common denominators for MSP in Europe and also beyond. It is beyond doubt that spatial planning of sea areas:

- concerns four-dimensional maritime space (the sea surface and the lower part of troposphere above it, the water column, the sea bottom and the subsoil beneath it);

- encompasses both space and time;

- aggregates individual human preferences in relation to marine space by a process of public choice (although at times this choice is deficient in terms of uneven balance of power, see also Chap. 9 in this volume);

- concerns human activity and its consequences;

\footnotetext{
${ }^{6}$ HELCOM is the Helsinki Commission created as an executive body of the Convention for the Protection of the Marine Environment of the region of the Baltic Sea, drawn up in Helsinki on March 22, 1974. In 1992, the previous international agreement was replaced with a Convention for the Protection of the Marine Environment of the region of the Baltic Sea, drawn up in Helsinki on April 9, 1992.
} 


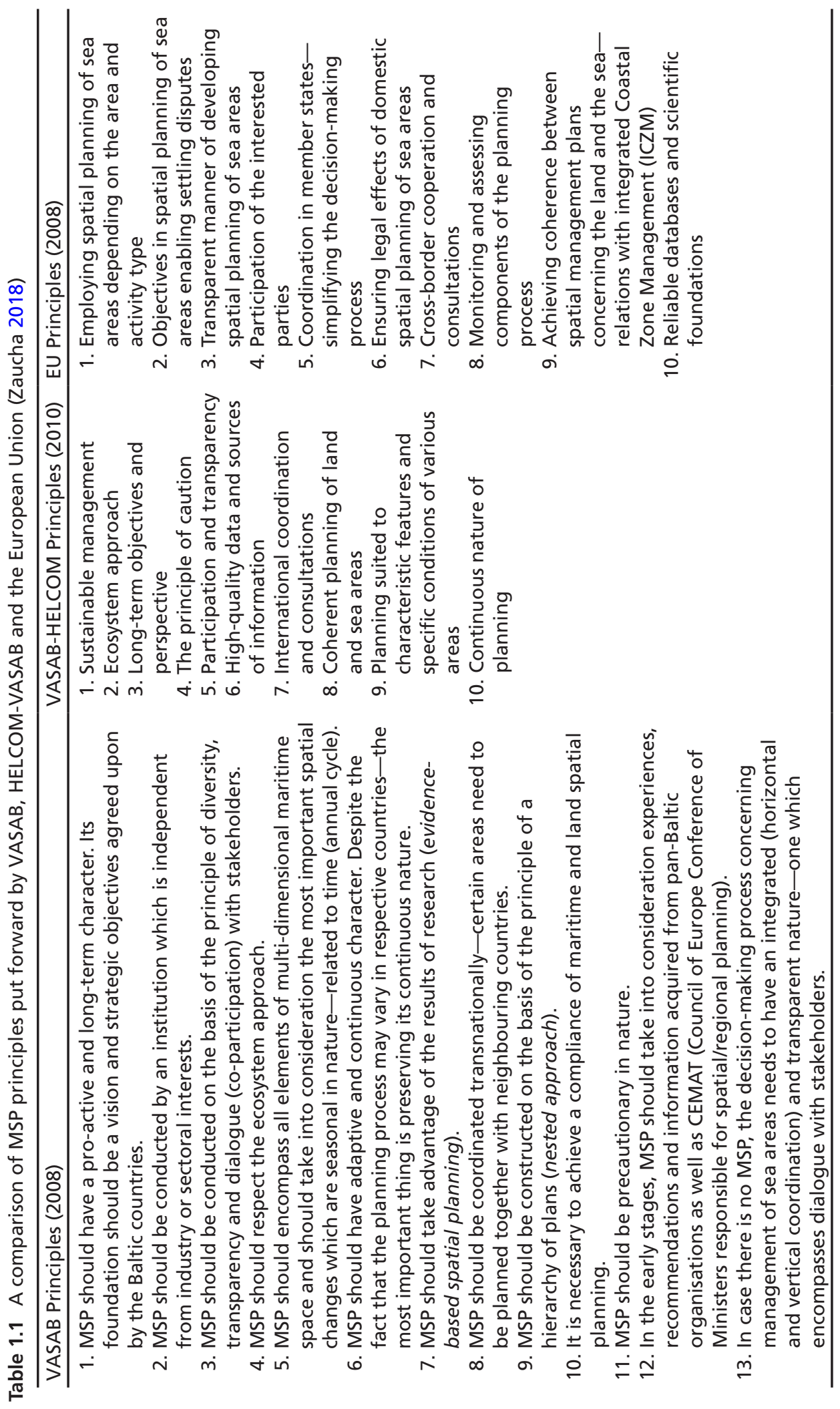


- is integrated (at least by definition);

- refers to the sea as a functional ecosystem;

- influences market processes at sea;

- requires transnational coordination within sea basins;

- requires coordination and connection with spatial planning on land;

- is conducted in a continuous and adaptive manner encompassing monitoring and evaluation; and

- employs — as best as it can—available research and information.

The most important differences of opinions concerning the essence and methods of MSP relate to:

- the degree of generality/specificity and the stage during which the aggregation of individual preferences into collective preferences occurs;

- relations between planning and management (in literature on the subject, e.g. Griffin (2006), planning is perceived as a function of management; however, some identify planning with management, for example, Tyldesley (2004, 4) or Ehler and Douvere (2009), who directly speak of a marine spatial management plan-hence the numerous discussions concerning relations of MSP and coastal zone management);

- the degree of specificity, integration and legal power of maritime spatial plans (e.g. in Norway marine spatial plans do not constitute a binding law but fulfil regulatory functions through the existing responsibilities of competent authorities);

- the degree of specificity and scope of data and information required for MSP; and

- the scope and methods of mobilising (engaging) stakeholders in the MSP process.

This last point relates to the fact that in research at least, the view has come to dominate that the process can be more important than the output of MSP (Payne et al. 2011). While some still regard MSP as simple regulatory plans that form a framework for administrative decision-making, it is increasingly evident that modern governance processes require more sophisticated techniques than administrative solutions and top-down directives as evidenced by terrestrial experiences (Faludi 2010, 21-23; 2015, 17; Healey 2000, 112-113; 2010, 226-227; Dühr et al. 2010, 102-111). Emphasising the process-based dimension means to emphasise (changing) social preferences regarding spatial management - a view that is also prevalent in the community of MSP practitioners. For example, Tomas Andersson, spatial planner and pioneer of MSP 
in Sweden, ${ }^{7}$ describes MSP as "a process to prepare society to meet an uncertain future and try to guide the development of space (and the use of resources) in a desirable direction". Process-based planning often makes use of vision-based tools or employs scenarios, and uses the degree of mobilisation as a measure of success. Planning with an emphasis on the process, however, requires time and human resources as well as patience (e.g. Morf et al. forthcoming), not least because an iterative, adaptive approach might sometimes be interpreted as a lack of progress. In addition, it also requires intuition and experience on the part of planners-and a fine sense of timing, for example, when to present results to political decision-makers or when to begin a new planning cycle (see also Chap. 19 in this book).

Table 1.2 is a general typology of different MSP approaches, corresponding objectives and the types of planning documents that might be produced as a result. It highlights that MSP has numerous other methods of implementing collective choices for marine space apart from regulatory plans-including a scenario (see also Chap. 14 in this book), a vision or another form of capturing spatial arrangements over time.

\section{Ten Common Misunderstandings and Key Areas for Future Research}

Based on the above, and reflecting many conversations and discussions with researchers and practitioners on MSP, we end by listing some common misunderstandings with regard to MSP. We argue that these are also critical fields of research on MSP, although many other research topics could probably be added.

First, despite its origins within the field of conservation, MSP is not an exclusive domain of environmental protection. The ecosystem approach, one of the principles of MSP in the EU, emphasises the importance of achieving good ecological status for the sea. But the ecosystem approach also seeks to secure "permanent use of sea resources and services by present and future generations" (EC 2008a, art. 1). Humans constitute an integral part of the ecosystem; therefore, it is necessary to integrate protection and use. This comes back to issues related to the guiding principle of MSP - what are the core values it is attempting to promote, and how can sustainability be translated into practice?

${ }^{7}$ Speech during the 2016 Baltic Days in St. Petersburg, pers. comm. 


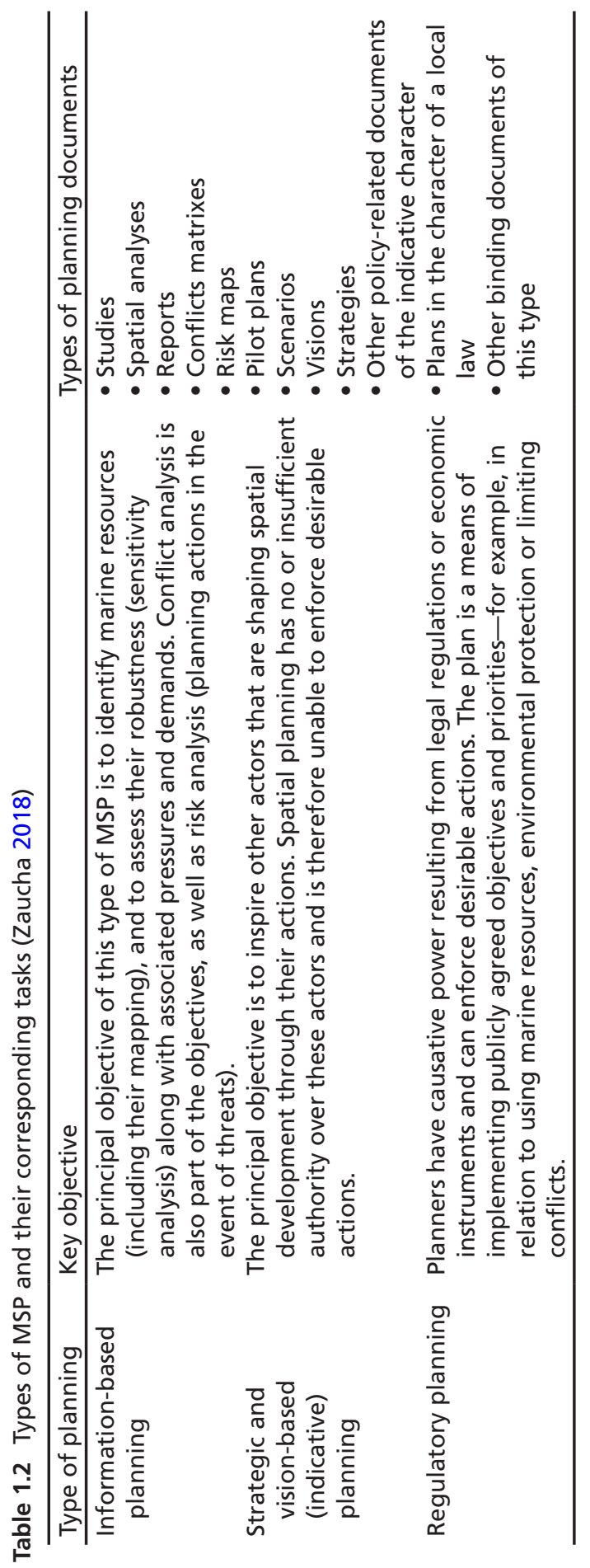


Second, continuing this line of thinking, MSP is not a universal remedy. Some challenges require solutions other than spatial planning. For example, in relation to eutrophication, spatial planning can only contribute to solutions but not resolve the original issue. Interactions and cooperation with other processes and policy areas are therefore essential if MSP is to play its part in the greater scheme of ocean governance. This also relates to the transboundary nature of MSP and its reliance on various forms of integration, resulting in a coherent approach to management supported by multiple policies (see later in this chapter).

Third, MSP does not-and should not-replace sectoral planning and programming. Space is an integrative concept, but like its terrestrial counterpart, MSP requires understanding of the various sectoral interests in this space. Understanding sectoral interests also extends into the social sphere and the preferences of society at large, such as aesthetic preferences with respect to landscapes. Non-material values and preferences need to be revealed and understood in order to be placed alongside the more commercial interestsrequiring the engagement of social sciences and researchers to ensure they can be fully integrated in the MSP process.

Fourth, MSP should not be confused with licensing, permitting, or similar processes of granting permission to use marine space. Even where a maritime spatial plan exists, permits and the associated processes of environmental impact assessment are a key requirement for using that space responsibly. This is related to the fact that even today, the marine environment and human impacts of use are poorly understood. Even where human interference with marine ecosystems seems acceptable, this should be verified through detailed analyses and research.

Fifth, MSP is not a one-time choice. Social preferences regarding maritime space are subject to dynamic changes, suggesting the need for continuous reinterpretation. Drawing up and approving a plan is merely a precursor for another plan that builds on the experiences of the first. Planning processes are therefore also learning processes, and MSP institutions must see themselves as learning institutions. It is encouraging that this fact is being recognised by countries engaged in revisions of their first marine/maritime spatial plans, although it must also be noted that the general thrust of MSP is unlikely to change in revisions of a plan, suggesting a degree of path dependency. Germany, for example, commencing its revision of the 2009 maritime spatial plan for the Exclusive Economic Zone (EEZ) in 2019, is determined to improve on the first planning process, which to a large extent was still experimental. In this context, the lack of a definitive plan is not a failure when a diligent planning 
process has taken place that changed stakeholder awareness and revealed tacit knowledge about the sea.

Sixth, MSP is more than drawing lines on a map. As stated in the beginning of this chapter, planning encompasses all the various actions that lead to rational spatial development. Spatial allocation is an important activity but only one among many. A vital element of MSP, for example, is defining the rules and principles to be used in location processes, as well as the rules for the negotiation processes that constitute MSP. A distinguishing feature of MSP in this context is its integrated approach, that is, its ability to analyse correlations, such as the mutual interactions of various (future) sea uses, cumulative pressures and their impacts on the functioning of the marine ecosystem. This in turn requires good collaboration with science and research to enable MSP to be evidence-led, as well as to recognise existing uncertainties and deal with them accordingly (e.g. through the precautionary principle or by making them transparent).

Seventh, MSP is conducted at multiple scales, encompassing both horizontal and vertical dimensions. A distinguishing feature of the sea is its higher geographical continuity of ecosystems, requiring a coherent approach to management across administrative boundaries. This may be achieved by a set of shared principles concerning the organisation of the MSP process, or by agreeing on shared objectives for ocean management, or a nested hierarchy of plans, for example. Yet achieving coherence is no easy feat, especially when maritime spatial plans are also influenced by regional and local plans or other strategic documents. Challenges related to integration have recently been evaluated by the BaltSpace project, focusing on policy and sector, stakeholder and knowledge integration (Saunders et al. 2016). Achieving integration in all these dimensions requires collaboration and coordination-and with this, understanding of the specific enablers and barriers to both. This is particularly important in international contexts as planning cultures may differ across borders but also within countries where institutional cultures and the respective value bases may also diverge.

Eighth, MSP is not an ideal process. It is a social process, and as such its benefits may diverge from what is expected. MSP might be a source of considerable drawbacks-for example, if it is appropriated by well-organised powerful interest groups or if risks associated with the MSP process are not taken into account (see also Chap. 15 in this book). The social dimensions of MSP are currently the subject of one of the most intense and heated scientific debates in MSP research, and it has been pointed out that rather than a "rational" process, MSP is in fact a highly politicised process. Rather than the ecological or economic results of the plan (see Chap. 9 in this book; Boucquey 
et al. 2016), the focus is therefore increasingly shifting to the sociopolitical results of the MSP process. This involves aspects such as power and the distribution of benefits achieved by the plan (Flannery et al. 2016). There also appears a postulate of phronetic evaluation of MSP (Kidd and Ellis 2012; Flyvbjerg 2004; Kidd and Shaw 2014). Therefore, MSP cannot be treated uncritically as an unquestioningly positive process. Continuous monitoring and evaluation are required not only of economic and ecological results but also of the social effects of this process. In countries only beginning MSP efforts, it is essential to develop awareness and build capacity among stakeholders to prevent MSP from being dominated by the strongest interest groups.

Ninth, there is an issue regarding the efficiency of MSP. Generally, efficiency is brought down to the design and implementation of the planning process which is supposed to lead to "balanced" outcomes (cf. e.g. Saunders et al. 2016). Mistakes in process design and implementation can lead to social resistance and a lack of legitimacy of the planning process, thereby reducing process efficiency. At the same time, mistakes and extra time spent on a process can be instrumental in promoting learning, and failures can ultimately act to improve relations between planners and stakeholders-forcing both sides to approach each other, forcing compromise and forcing both sides to engage with each other's viewpoints. This takes time and continuity-for example, in terms of staffing, in order to build the required level of trust. Engaging with efficiency also takes evaluation and a critical assessment of the process (see Chap. 18 in this book).

And last not least, there is the issue of working with stakeholders in a meaningful way. Many experiences have shown that tokenistic involvement will not lead to the desired results, but that long-term and honest commitment is necessary. Research that contributes to understanding stakeholders, their core values and motivations, as well as mechanisms for successful process design, is therefore of key importance for MSP in the future.

\section{Conclusion}

This chapter has attempted to sketch the development of MSP from its initial conceptualisation as a zoning tool for marine conservation to a multidimensional approach to spatial marine governance. MSP is continuing to develop as a practice around the world, although the number of initiatives that have reached the implementation stage is still comparatively low: Out of a total of 60 MSP initiatives in 2017,37\% were at the pre-planning stage, 
$33 \%$ at the plan preparation stage and 19\% had an approved plan. Eleven per cent have gone as far as revising their plans, with some countries like the Netherlands now in their third cycle of MSP (Ehler 2017). Many plans cover the EEZ, sometimes encompassing large sea areas as a result. Conflicts among uses still constitutes the most common driving force for MSP, closely followed by the need for a more integrated approach and concerns about marine conservation and new and emerging uses, indicating that strategic use of MSP as part of targeted development planning for the sea is still less well developed. The greater proportion of maritime spatial plans is also advisory rather than regulatory, although many rely on other authorities for the implementation of management plans (Ehler 2017).

Given the current level of interest in MSP and the political support it has in many regions of the world, the number of countries engaging with MSP is set to increase. It has been estimated that by 2030, a third of the world's EEZs will be covered by government-approved maritime spatial plans (Ehler 2017) — with the possibility of extending even further into areas beyond national jurisdiction (see also Chap. 17 in this book). Views on whether this is desirable or not are likely to vary, not least in line with different interpretations of MSP as a concept.

What is certain is that MSP will continue to face challenges. At a practical implementation level, a key challenge is that MSP requires authority in order to be effective, which takes time to establish. Added to this is the fact that MSP is rarely free, but requires the allocation of (often scarce) government funds. Moreover, MSP usually requires painful decisions related to various trade-offs and this might decrease its acceptance. Win-win situations are rare in contemporary MSP. Methodological challenges are likely to arise from different practices of MSP, not least from evaluating them in order to assess the actual benefits of MSP. Also planning culture and experience varies among countries. Is MSP worth the effort, and what kind of MSP yields which benefits to whom, how and when? Is it possible to generalise or is effective MSP always context-specific? Another challenge is that MSP does not occur in isolation but requires transnational cooperation-which may not be an easy feat in times of increasing international strife and competition. Climate change is likely to pose its own challenges, related for example to adaptiveness of marine/maritime spatial plans but also linked to geostrategic issues, such as exploitation of the Arctic. Interdisciplinary and transdisciplinary efforts are required for successfully addressing these and other issues, requiring the expertise of a wide range of scientists and practitioners today and in the next generation. 
Acknowledgements The authors are grateful to the project "Economy of maritime space" funded by the Polish National Science Centre for contributing the Open Access fee for this chapter and facilitating our discussions and preparation of the book. The Maritime Institute in Gdansk also partially paid the Open Access fee.

\section{References}

Acker, H., \& Hodgson, S. (2008). European Commission Legal Aspects of Maritime Spatial Planning. Final Report to DG Maritime Affairs \& Fisheries. MRAG, Framework Service Contract, No. FISH/2006/09—LOT2.

Anderson, J., \& Peters, J. K. (2014). Water Worlds: Human Geographies of the Ocean. Farnham, Surrey and Burlington, VT: Ashgate Publishing, 214 pp.

Ansong, J., Calado, H., \& Gilliland, P. (2018). A Multifaceted Approach to Building Capacity for Marine/Maritime Spatial Planning: Review and Lessons from Recent Initiatives. Marine Policy (Submitted).

Blasbjerg, M., Pawlak, J. F., Sørensen, T. K., \& Vestergaard, O. (2009). Marine Spatial Planning in the Nordic Region Principles, Perspectives and Opportunities. Copenhagen: Nordic Council of Ministers.

Boucquey, N., Fairbanks, L., Martin, K. S., Campbell, L. M., \& McCay, B. (2016). The Ontological Politics of Marine Spatial Planning: Assembling the Ocean and Shaping the Capacities of 'Community' and 'Environment'. Geoforum, 75, 1-11. Carneiro, G. (2013). Evaluation of Marine Spatial Planning. Marine Policy, 37, 214-229.

Cormier, R., Kannen, A., Elliott, M., \& Hall, P. (2015). Marine Spatial Planning Quality Management System. ICES Cooperative Research Report 327. Retrieved December 31, 2016, from http://www.ices.dk/sites/pub/publication\%20reports/ cooperative $\% 20$ research $\% 20$ report $\% 20$ (crr)/crr327/marine $\% 20$ spatial\%20planning\%20quality\%20management\%20system $\% 20 \mathrm{crr} \% 20327$.pdf.

Day, J. C. (2002). Zoning-Lessons from the Great Barrier Reef Marine Park. Ocean \& Coastal Management, 45(2-3), 139-156.

Douvere, F. (2008). The Importance of Marine Spatial Planning in Advancing Ecosystem-Based Sea Use Management. Marine Policy, 32, 762-767.

Douvere, F., \& Ehler, C. (Eds.). (2008). Special Issue on the Role of Marine Spatial Planning in Implementing Ecosystem-Based Sea Use Management. Marine Policy, 32(5), 759-843.

Douvere, F., \& Ehler, C. (2009a). Ecosystem-based Marine Spatial Management: An Evolving Paradigm for the Management of Coastal and Marine Places. Ocean Yearbook, 23, 1-26.

Douvere, F., \& Ehler, C. (2009b). New Perspectives on Sea Use Management: Initial Findings from European Experience with Marine Spatial Planning. Journal of Environmental Management, 90, 77-88. 
Dühr, S., Colomb, C., \& Nadin, F. (2010). European Spatial Planning and Territorial Cooperation. London and New York: Routledge, 452 pp.

EC. (2006). Green Paper Towards a Future Maritime Policy for the Union: A European Vision for the Oceans and Seas. Brussels, 7.6.2006 COM(2006), 275 final, Vol. II.

EC. (2007a). Communication from the Commission to the European Parliament, the Council, the European Economic and Social Committee and the Committee of the Regions. An Integrated Maritime Policy for the European Union. Brussels, 10.10.2007, $\operatorname{COM}(2007), 575$ final.

EC. (2007b). Accompanying Document to the Communication from the Commission to the European Parliament, the Council, the European Economic and Social Committee and the Committee of the Regions. An Integrated Maritime Policy for the European Union. Brussels, 10.10.2007, SEC(2007) 1278.

EC. (2008a). Directive 2008/56/EC of the European Parliament and of the Council of 17 June 2008 Establishing a Framework for Community Action in the Field of Marine Environmental Policy Marine Strategy Framework Directive. Official Journal of the European Union, L 164.

EC. (2008b). Roadmap for Maritime Spatial Planning: Achieving Common Principles in the EU. Brussels, 25.11.2008, COM(208) 791.

EC. (2014a). Directive 2014/89/EU of the European Parliament and of the Council of 23 July 2014 Establishing a Framework for Maritime Spatial Planning. Official Journal of the European Union, L 257/135.

EC. (2014b). Commission Staff Working Document A Sustainable Blue Growth Agenda for the Baltic Sea Region. Brussels, 16.5.2014 SWD(2014) 167 final.

EC. (2016). Communication from the Commission to the European Parliament, the Council, the European Economic and Social Committee and the Committee of the Region. International Ocean Governance: An Agenda for the Future of Our Oceans. Brussels, 10.11.2016, JOIN(2016) 49 final.

Ehler, C. (2014). A Guide to Evaluating Marine Spatial Plans. IOC Manuals and Guides No. 70, ICAM Dossier 8. Paris: UNESCO, Intergovernmental Oceanographic Commission UNESCO IOC, 96 pp.

Ehler, C. (2017). World-Wide Status and Trends of Maritime/Marine Spatial Planning. Presented at the 2nd International Conference on Marine/Maritime Spatial Planning, UNESCO, Paris.

Ehler, C., \& Douvere, F. (2007). Visions for a Sea Change. Technical Report of the International Workshop on Marine Spatial Planning, November 8-10, 2006. Paris: Intergovernmental Oceanographic Commission, UNESCO. IOC Manual \& Guides No. 46, ICAM Dossier 3.

Ehler, C., \& Douvere, F. (2009). Maritime Spatial Planning. A Step-by Step Approach. Toward Ecosystem-based Management. Manual and Guides No 153, ICAM Dossier No. 6. Paris: Intergovernmental Oceanographic Commission UNESCO IOC, $99 \mathrm{pp}$. 
Ekebom, J., Jäänheimo, J., \& Reker, J. (Eds.). (2008). Towards Marine Spatial Planning in the Baltic Sea BALANCE WP4 Final Report.

Faludi, A. (2010). Beyond Lisbon: Soft European Spatial Planning. disP-The Planning Review, 46(182), 14-24.

Faludi, A. (2013). Territory: An Unknown Quantity in Debates on Territorial Cohesion. European Journal of Spatial Development. Refereed Article No. 51.

Faludi, A. (2015). Place Is a No-Man's Land. Geographia Polonica, 88(1), 5-20.

Flannery, W., Ellis, G., Ellis, G., Flannery, W., Nursey-Bray, M., van Tatenhove, J. P., Kelly, C., Coffen-Smout, S., Fairgrieve, R., Knol, M., \& Jentoft, S. (2016). Exploring the Winners and Losers of Marine Environmental Governance/Marine Spatial Planning: Cui bono?/"More than Fishy Business": Epistemology, Integration and Conflict in Marine Spatial Planning/Marine Spatial Planning: Power and Scaping/Surely Not All Planning Is Evil?/Marine Spatial Planning: A Canadian Perspective/Maritime Spatial Planning_ "ad utilitatem omnium"/ Marine Spatial Planning: "It Is Better to Be on the Train than Being Hit by It"/ Reflections from the Perspective of Recreational Anglers.... Planning Theory and Practice, 17, 121-151.

Flyvbjerg, B. (2004). Phronetic Planning Research: Theoretical and Methodological Reflections. Planning Theory and Practice, 5(3), 283-306.

Gilliland, P. M., \& Laffoley, D. (2008). Key Elements and Steps in the Process of Developing Ecosystem-Based Marine Spatial Planning. Marine Policy, 32, 787-796.

Griffin, R. W. (2006). Fundamentals of Management: Core Concepts and Applications. Boston: Houghton Mifflin, 559 pp.

Hassler, B., Blažauskas, N., Gee, K., Gilek, M., Janßen, H., Luttmann, A., Morf, A., Piwowarczyk, J., Saunders, F., Stalmokaite, I., Strand, H., \& Zaucha, J. (2017). BONUS BALTSPACE D 2:2: Ambitions and Realities in Baltic Sea Marine Spatial Planning and the Ecosystem Approach: Policy and Sector Coordination in Promotion of Regional Integration. Huddinge: Södertörn University.

Healey, P. (2000). Institutionalist Analysis, Communicative Planning, and Shaping Places. Journal of Planning Education and Research, 19(2), 111-121.

Healey, P. (2010). Making Better Places-The Planning Project in the Twenty-First Century. London: Palgrave.

Heinrichs, B., Schultz-Zehden, A., \& Toben, S. (2005). The Interreg III B Balt Coast Project. A Pilot Initiative on Integrated Coastal Zone Management in the Baltic Sea (2002-2005), Coastline Reports 2005 no. 5.

HM Government. (2011). UK Marine Policy Statement. London: The Stationery Office Limited.

IOPTF. (2010). Final Recommendations of The Interagency Ocean Policy Task Force. Washington, DC: The White House Council on Environmental Quality. Jay, S. (2012). Marine Space: Manoeuvring Towards a Relational Understanding. Journal of Environmental Policy and Planning, 14(1), 81-96. 
Jay, S., Flannery, W., Vince, J., Liu, W. H., Xue, J., Matczak, M., Zaucha, J., Janssen, H., van Tatenhove, J., Toonen, H., Morf, A., Olsen, E., Vivero, J., Mateos, J., Calado, H., Duff, J., \& Dean, H. (2013). International Progress in Marine Spatial Planning. In A. Chircop, S. Coffen-Smout, \& M. McConnel (Eds.), Ocean Yearbook 27 (pp. 171-212). Leiden: Martinus Nijhoff Publishers.

Kidd, S., \& Ellis, G. (2012). From the Land to Sea and Back Again? Using Terrestrial Planning to Understand the Process of Marine Spatial Planning. Journal of Environmental Policy and Planning, 14(1), 49-66.

Kidd, S., \& Shaw, D. (2014). The Social and Political Realities of Marine Spatial Planning: Some Land-Based Reflections. ICES Journal of Marine Science, 71(7), $1535-1541$.

Merrie, A., \& Olssen, P. (2014). An Innovation and Agency Perspective on the Emergence and Spread of Marine Spatial Planning. Marine Policy, 44, 366-374.

Morf, A., Strand, H., Gee, K., Gilek, M., Janssen, H., Hassler, B., Luttman, A., Piwowarzyk, J., Saunders, F., Stalmokaite, I., \& Zaucha, J. (forthcoming). Peer Reviewed Version of BONUS BALTSPACE Deliverable 2.3 Report, Swedish Institute for the Marine Environment Report Series, Swedish Institute for the Marine Environment, University of Gothenburg, Gothenburg, Sweden.

MSPP. (2006). Marine Spatial Planning Pilot. Final Report. MSPP Consortium. Retrieved May 15, 2018, from http://www.abpmer.net/mspp/docs/finals/ MSPFinal_report.pdf.

OECD. (2016). The Ocean Economy in 2030. Paris: OECD Publishing.

Olsson, P., Folke, C., \& Hughes, T. P. (2008). Navigating the Transition to EcosystemBased Management of the Great Barrier Reef, Australia. Proceedings of the National Academy of Science of the US A, 105(28), 9489-9494.

Payne, I., Tindall, C., Hodgson, S., \& Harris, C. (2011). Comparison of National Maritime Spatial Planning (MSP) Regimes Across EU. IN: Comparative Analysis of Maritime Spatial Planning (MSP) Regimes, Barriers and Obstacles, Good Practices and National Policy Recommendations. "Seanergy 2020". Retrieved December 29, 2016, from http://www.seanergy2020.eu/wp-content/ uploads/2011/07/110707_final-deliverable-d.2.31.pdf.

Ratzel, F. (1882). Antropho-Geographie. Stuttgart: J. Engelhorn, 526 pp.

Santos, C. F., Ehler, C. N., Agardy, T., Andrade, F., Orbach, M. K., \& Crowder, L. B. (in press). Marine Spatial Planning. In C. Sheppard (Ed.), World Seas: An Environmental Evaluation (Vol. III). Elsevier.

Saunders, F., Gilek, M., Gee, K., Göke, C., Hassler, B., Lenninger, P., Luttmann, A., Morf, A., Piwowarczyk, J., Schiele, K., Stalmokaite, I., Strand, H., Tafon, R., \& Zaucha, J. (2016). Exploring Possibilities and Challenges for MSP Integration in the Baltic Sea. Stockholm: Bonus BaltSpace. Retrieved December 7, 2017, from http://www.baltspace.eu/index.php/published-reports.

Schultz-Zehden, A., Gee, K., \& Scibior, K. (2008). Handbook on Integrated Maritime Spatial Planning. Berlin: S.PRO, 98 pp. 
SWAM. (2014). Marine Spatial Planning—Current Status 2014. National Planning in Sweden's Territorial Waters and Exclusive Economic Zone (EEZ). Gothenburg: The Swedish Agency for Marine and Water Management.

Tyldesley, D. (2004). Coastal and Marine Spatial Planning Framework for the Irish Sea Pilot Project. London: Defra. Retrieved from http://jncc.defra.gov.uk/pdf/ Tyldesley\%20Marine\%20spatial\%20planning.pdf.

VASAB. (2001). Wismar Declaration and VASAB 2010+ Spatial Development Action Programme. Wismar: VASAB 2010.

Zaucha, J. (2008). Sea Use Planning and ICZM Input to the Long Term Spatial Development Perspective. Final Report from Working Group 3. Riga: Vision and Strategies Around the Baltic Sea. Retrieved May 27, 2018, from http://www. vasab.org/east-west-window/documents.html.

Zaucha, J. (2009). The Marine Economy in the Face of New Development Trends (Spatial Aspects). In T. Markowski (Ed.), The Polish Spatial Development Concept Versus European Vision of Spatial Development Perspectives (pp. 134-156). Warsaw: Polish Academy of Science, Committee for Spatial Economy and Regional Planning.

Zaucha, J. (2013). Programming Development of the Baltic Sea Region. In T. Kudłacz \& D. Woźniak (Eds.), Programming Regional Development in Poland. Theory and Practice. Studies of Polish Academy of Science, Committee for Spatial Economy and Regional Planning, 35: 177-190.

Zaucha, J. (2014). The Key to Governing the Fragile Baltic Sea. Maritime Spatial Planning in the Baltic Sea Region and Way Forward. Riga: VASAB. 110 pp.

Zaucha, J. (2018). Gospodarowanie przestrzeniq morska. Warszawa: Instytut Rozowju i Sedno, 408 pp.

Open Access This chapter is licensed under the terms of the Creative Commons Attribution 4.0 International License (http://creativecommons.org/licenses/by/4.0/), which permits use, sharing, adaptation, distribution and reproduction in any medium or format, as long as you give appropriate credit to the original author(s) and the source, provide a link to the Creative Commons licence and indicate if changes were made.

The images or other third party material in this chapter are included in the chapter's Creative Commons licence, unless indicated otherwise in a credit line to the material. If material is not included in the chapter's Creative Commons licence and your intended use is not permitted by statutory regulation or exceeds the permitted use, you will need to obtain permission directly from the copyright holder. 